\title{
The Impact of the Covid-19 Pandemic on Reserve Adequacy: Evidence From Middle Income Countries
}

\author{
Maru Etta-Nkwelle \\ Howard University \\ Carlton Augustine \\ Cyril Kenrick Hunte \\ Howard University
}

In order to examine the impact of the COVID-19 pandemic on reserve adequacy levels in 70 middle income EMC's we employ the IMF'S risk weighted metric, along with three other standard measures. Our research suggests that over $50 \%$ of these countries were ill-prepared to handle the financial risks posed by COVID19 beyond 2020. We find that the demand for international reserves during the study period emphasized financial stability, rather than trade related vulnerabilities. We observed that reserve demand is influenced by the need to meet a more broad-based adequacy level, with less emphasis on individual sectorial vulnerabilities. Additionally, the financial stability variables, such as the dummy variable for the fixed exchange rate, broad money/reserves, and short-term debt/ reserves, carry a greater proportion of the weights than the trade related variables, namely, (export + import)/GDP, export/GDP, and import/GDP. This finding lends support to the notion that the motivations for holding reserves by EMCs may be shifting away from trade related vulnerabilities and moving towards mitigating susceptibilities in the financial sector.

Keywords: foreign currency reserves, reserve adequacy, Covid-19, fixed exchange rate regimes, floating exchange rate regimes

\section{INTRODUCTION}

The Covid-19 pandemic has adversely affected the economies of many countries. In this regard, there is the concern of whether emerging market countries (EMCs) have sufficient foreign currency reserves (FCRs) and capital inflows to maintain consumption and production levels beyond one year. Additionally, Rojas-Suarez (2020) argued that the large external debt of EMCs which stood at 6.7 trillion (excluding China) in 2019, together with their dwindling net-capital inflows, position these countries in a vulnerable position, should Covid-19 linger. Evidence suggests that the accumulation of FCRs, and sound economic policies, cushioned EMCs from the full effect of the Global Financial Crisis of 2007-2009; and this enabled these countries to maintain production and consumption at relatively high levels (Arslan and Cantu, 2018; IMF, 2011). Consequently, most central banks sought to accumulate significant levels of FCRs as part of 
their domestic economic strategy, with the result that FCRs in EMCs grew from 25 percent of GDP in 2010 to 30 percent of GDP in 2018 (Arslan and Cantu, 2018).

This accumulation of reserves re-opened the debate about the motives for reserves accumulation. Ghosh et al (2014) asserted that current account vulnerabilities, such as a sharp drop in export earnings or a huge increase in imports, strengthened the case for reserve accumulation. This approach of reserve accumulation supported the notion by Aizenman and Lee (2007) and the IMF- ARA (2013) that the precautionary motive for holding reserves is still a priority for EMCs, as it continues to carry more weight than other factors, such as export promotion and exchange rate maintenance. Notwithstanding these findings, and after the Asian financial crisis of the 1990s, a growing literature emerged in which it was purported that reserve demand should go beyond protection against current account vulnerabilities. This was premised on the idea that it should include domestic strategic goals, such as export promotion, maintain a peg, and crisis management (Aizenman and Lee, 2007; Ghosh et. al, 2017).

Acknowledging the concerns raised above, the purpose of this paper is to examine whether the EMCs pre-Covid-19 FRCs are sufficient to mitigate a Covid-19 cash inflow shortfall; and to ascertain what other factors can impact the demand for FCRs during the world-wide Covid-19 pandemic. Furthermore, noting that there is the potential for diverse pathways for leakages from EMCs international reserves that is precipitated by Covid-19 risks; and recognizing that a broad- based approach is required for better coverage than what is observed in the traditional methods, we employ in our paper the risk weighted metric procedure proposed by the IMF (2011). The remaining sections of this paper are as follows. A short literature review in section 2 will be followed by a description of the model in Section 3, while results and conclusions will close out the paper in sections 4 and 5, respectively.

\section{REVIEW OF LITERATURE}

Prior to the $1990 \mathrm{~s}$, the leading motivation for holding reserves was to facilitate international transactions and cushion terms of trade shocks (Arslan and Cantu, 2018; Aizenman and Marion, 2003). This was necessary, given that most emerging market countries at the time depended on primary, export products that encountered volatile export prices in international markets. In the 1990s, several countries such as Argentina, Mexico and Turkey experienced financial crises which resulted in severe economic disruption. An explanation for these crises was the sudden-stop or double drain phenomena that resulted in the simultaneous loss of external funds and capital flight (Obstfeld et al., 2010). From these experiences, countries found it necessary to accumulate reserves in order to present a buffer to offset the impact of the sudden-stops, often referred to as the precautionary or self-insurance motive (Fischer, 2001). The precautionary motive remains a priority for EMCs, because of their trade composition and the uncertainty surrounding their cash inflows. Furthermore, with the contagion brought on by the Asian financial crisis in the 1990s, capital account vulnerabilities that included non-resident withdrawal of assets or capital flight, and crisis management have become increasingly important (Summer, 2006). Apart from precautionary and crisis management motives, Ho and McCauley (2003) suggest price stability as a motivating factor for accumulating reserves in which excess reserves are used to dampen price fluctuations in EMCs. They also add that this approach is particularly true for exchange rate regimes that are highly managed (such as China), where reserve accumulation is used to reduce exchange rate volatility and the consequential pass-through to inflation.

While there were concerns about the growth in reserves in the 2000s, Olivier (2007) and Summers (2006) indicated that the risk of a capital account crisis was relatively low. Consequently, this outcome could not justify the levels of accumulation for self-insurance, since reserves were instrumental in smoothing consumption levels, and averting banking and currency crises, given the smaller currency depreciations that EMCs would have experienced (IMF, 2011). After the recession of 2007-2009, Arslan and Cantu, (2018) noted that oil producing countries, including Saudi Arabia, have accumulated large reserves as a buffer to offset the wild swings in oil prices. Ahmad (2020) cites the case of China which practices a managed float and can raise the value of the US dollar relative to the Yuan as an export promotion strategy. This has the effect of making Chinese goods cheaper than American made goods, 
thereby increasing China's export earnings; and associating this approach with the mercantilist export led growth model (Park and Estrada, 2009).

Ghosh et. al (2017) estimated a model with three sets of variables meant to capture the importance of current and capital account risks and mercantilism for 43 EMCs. They found that the coefficient of the precautionary variables in the post Asian financial crisis period was lower than that in the pre-Asian financial crisis period. They also showed currency undervaluation, which served as a proxy for mercantilism, was insignificant in the pre-crisis period, but positive and significant in the post crisis period. While little evidence has been found to support the mercantilist view, advocates argue that countries sometimes will maintain undervalued currencies to increase aggregate demand, export receipts and reserves (Bar-llan and Marion, 2009; Aizenman and Lee, 2008). Because of the relative importance of reserves in the domestic strategy of EMCs, Ghosh et al. (2017) add that as more EMCs have become financially open, they have more access to international capital markets. This access cushions their short-term liquidity needs and reduces their demand for reserves. But other authors (Borio and Disyatat, 2015) argue that EMCs, whose economies are highly integrated with the global economy, such as China and Malaysia, still need above normal reserves to cushion capital account shocks that can stem from capital flight, and the sudden reduction in foreign aid, remittances, and foreign direct investment.

Equally important to the reserve accumulation discussion is the question of adequacy. One of the earlier measures developed to ensure adequacy is the import cover. The import cover rule suggests that reserves should be able to cover three to six months of imports. This rule is recommended for countries with capital controls and limited access to capital markets (IMF, 2016). In the aftermath of the Asian financial crisis in the 1990s, the Guidotti-Greenspan rule proposed that countries hold reserves such that they can survive without capital inflow for at least one year. This implies that emerging market countries should hold FCRs of at least the sum of short-term debt plus any current account deficits to mitigate sudden-stop vulnerabilities, which can stem from increased access to international capital markets (IMF, 2016). Another rule that emerged in 2000, which is based on monetary aggregates M2, has been expanded by Wijnholds and Kapteyn (2001). This rule conveyed the notion that during periods of domestic financial stress, the risk increases for the conversion of bank deposits into foreign currency (Csavas and Csom-Biro, 2017); and to mitigate the risk of capital flight, the IMF (2011) recommended that a 20 reserve to M2 ratio be maintained.

Measures of reserve adequacy have progressed from the traditional trade related risks to metrics- based measures that emphasize the unique strengths and/or weaknesses of the fundamentals of each country. In a series of policy papers, the IMF $(2011,2013,2015)$ proposed a new metric for assessing reserve adequacy, namely, Assessment of Reserve Adequacy (ARA), that considers potential reserve drains from several sources. Lessons from the great recession of 2007-2009 precipitated the need for a broad-based, riskweighted measure similar to the capital requirements mandated for commercial banks. Interestingly, the Covid-19 global pandemic (recession) shut down market access, negatively impacting the income streams of many emerging market countries that rely on export income to meet their international obligations. A survey by Beck et al (2020) of 638 firms in ten emerging market countries found that 3 out of 4 firms suffered income shortfalls due to the Covid-19 shutdowns; and these firms had to depend on government financial assistance to obviate further labor layoffs and reduction in investment spending. It would appear also that these pressures seem to be lingering beyond the short-term, rendering traditional measures of reserve adequacy, such as 3-6 months of import cover and one year of short-term debt, inadequate. In these circumstances, the potential long term multisectoral drain on international reserves transforms the risk weighted measure employed in this paper as a timely indicator, since it takes into consideration foreign exchange reserve drains from several vulnerability sources as identified by the IMF. Meanwhile, the IMF (2011) risk weighted measure balances the need for simplicity and completeness by incorporating four sources of potential pressures, including export income (Exp), short-term external debt (STD); broad money (M2); and other portfolio liabilities (OPL). Shortfalls in export income can arise from decreases in external demand that negatively impact the current account. Samaratunga and Perera (2015) add that in times of crisis short term debt tend to deplete reserves quickly, resulting in the rapid depreciation of the exchange rate and the fall in equity prices. Additionally, the risk of capital flight by domestic residents to protect the 
value of their assets for fear of a currency depreciation increases during periods of crisis. And to counteract this outcome, the IMF applies the ratio of broad money to reserves to measure this risk.

Undoubtedly, the Covid-19 crisis has raised not only the measurement of risk, but also it has raised the question of reserve adequacy in EMCs. In this regard, one of the goals of our paper is to ascertain how some of the EMCs have managed this currently unabated crisis. Did the EMCs have adequate reserves to buffer against the effects of the Covid-19 shocks and were they well-prepared to manage the crisis? Answers to this and related questions will be explored in this paper; but before doing so, the methodology employed in the paper is described in the next section.

\section{METHODOLOGY}

In this section, we employ three standard, and one contemporary measure to assess the 2019 reserve adequacy levels of 70 middle income emerging market countries. We compare the contemporary risk weighted measure to three standard measures: reserve to import (import cover); broad money to reserves (Wijnholds and Kapteyn rule, 2001); and reserves to short term debt (Guidotti-Greenspan rule,1999). We use data from the World Bank on the later three and estimated the risk weighted measure using IMF data (reserves minus gold) and IMF ARA 2014 established adequacy weights. To derive the weights (Table1), the IMF applies a two-stage approach where in the first stage, a risk weighted liability stock is developed, using the relative riskiness of diverse potential drains on reserves during periods of stress. The risk weights of the potential drains in each sector are then used to estimate the desired proportion of reserves that should be held during crisis periods. The IMF arbitrarily select drains observed at the 10th percentile of each distribution (given data limitations) which is a minor drawback of this method (IMF 2011). Based on this measure, the IMF suggests that reserves between 100 to 150 percent are considered adequate. The components that could potentially drain and EMCs international reserves and their corresponding risk weights proposed by the IMF are presented on Table.

TABLE 1

IMF 2013 REVISED RISK WEIGHTS PER COMPONENT

\begin{tabular}{|l|c|c|c|c|}
\hline \multicolumn{1}{|c|}{ In } & Short Term Debt & Other Liabilities & Broad Money & Exports \\
\hline Fixed Exchange Rate & 30 & 20 & 10 & 10 \\
\hline Floating Exchange Rates & 30 & 15 & 5 & 5 \\
\hline
\end{tabular}

Source: IMF ARA(2015)

We also estimate two conventional reserve demand functions and develop a third hybrid reserve demand model that incorporates a composite, risk weighted measure. The purpose of this hybrid model is to test whether the reserve demand is still geared towards covering current account vulnerabilities, as defined by the precautionary motive; or whether it is shifting towards a more broad-based adequacy level. Furthermore, mindful of the financial risk posed by Covid-19, we use the best performing model, defined by variables at the 1 percent level of significance, to forecast the 2020 reserve levels for a select few of the nations; and compare the actual values with the forecast for each of these countries.

We begin the estimation process by testing the stochastic nature of the time series data. Establishing stationarity conditions for the data set is important, because only then can we use the behavior of the series for forecasting purposes. To test for stationarity, a panel unit root test was performed using the Augmented Dickey-Fuller (ADF) and the Philips - Perron (PP) unit root test. The ADF test informs if the null hypothesis of a unit root at the first level can be rejected. The conducted test of stationarity rejected the null hypothesis of the presence of a unit root and found all the variables in the model to be stationary in levels, except for the import and M2 series that are reported in first difference (Table 2). 
TABLE 2

PANEL UNIT ROOTS TEST: RESERVE DEMAND VARIABLES

\begin{tabular}{|l|c|c|c|c|c|c|}
\hline Variables & Stat. & Prob. & Obs. & Stat. & Prob. & Obs. \\
\hline Reserve & 262.88 & 0.000 & 632 & 484.99 & 0.000 & 711 \\
\hline GDP & 240.64 & 0.000 & 553 & 392.90 & 0.000 & 632 \\
\hline Import* & 301.75 & 0.000 & 553 & 534.80 & 0.000 & 632 \\
\hline Export & 235.61 & 0.000 & 553 & 501.13 & 0.000 & 632 \\
\hline M2* & 262.73 & 0.000 & 553 & 535.55 & 0.000 & 632 \\
\hline STD & 252.25 & 0.000 & 624 & 271.93 & 0.000 & 702 \\
\hline Op. Cost & 933.92 & 0.000 & 632 & 970.81 & 0.000 & 711 \\
\hline
\end{tabular}

*First difference

Next, we perform a Johansen cointegration test to ascertain whether there is a long-run relationship between the variables. This analysis of the data confirm that the trace test results indicate three cointegrating equations at the 5 level (Table 3).

TABLE 3

PANEL TESTS OF COINTEGRATION: RESERVE AND ITS DETERMINANTS

\begin{tabular}{|l|c|c|c|c|}
\hline Null Hypothesis & Eigenvalue & $\begin{array}{c}\text { Trace } \\
\text { Statistics }\end{array}$ & Trace 5 critical value & Prob. \\
\hline $\mathrm{R}=0^{*}$ & 0.4845 & 664.22 & 69.81 & 0.0001 \\
\hline $\mathrm{R}$ at most ${ }^{*}$ & 0.2753 & 297.70 & 47.8561 & 0.0001 \\
\hline $\mathrm{R}$ at most ${ }^{*}$ & 0.1723 & 119.63 & 29.79 & 0.0001 \\
\hline $\mathrm{R}$ at most 3 & 0.0178 & 15.010 & 15.494 & 0.0590 \\
\hline $\mathrm{R}$ at most $4 *$ & 0.0090 & 5.0275 & 3.8414 & 0.0249 \\
\hline
\end{tabular}

*Denotes rejection of the hypothesis at the 5 level.

Since the diagnostic test suggests that there is a long-run relationship between the dependent and independent variables, the next step is to estimate the reserve demand equations using a suitable method for panel data. We follow Bastourre et al. (2009) and employ the Generalized Method of Moments (GMM) technique (Arellano and Bond, 1991), with instrumental variables to address the potential issues of dynamic specification and endogeneity. The variables included in our reserve demand functions are primarily motivated by the adequacy measures. We have included variables that proxy the rationale for which the adequacy measures were developed. The import cover measure is proxied using import to GDP. Since the precautionary motive for holding reserves has been the dominant reason for emerging markets demand for reserves, we included a trade openness variable for the model. A search of the literature reveals different proxies for trade openness, such as import to GDP + exports to GDP (Obstfeld, et al. 2002); export to GDP and import to GDP (Ghosh et. al, 2017). We have added these variations in two separate models to represent trade openness and current account vulnerabilities. We add a financial stability variable, namely, shortterm debt to GDP, to proxy the concern for domestic financial stability during periods of economic stress (Guidotti-Greenspan,1999); and M2 to GDP to measure the risk of capital flight, as identified in the rule by Wijnholds and Kapteyn (2001). Given that some of the emerging market countries in the sample have access to international financial markets and the choice to pursue other channels of investment, we have added the opportunity cost of holding reserves, proxied by the 10-year U.S. Treasury bond rate. The expectation is that the demand for reserves will reduce as other investment opportunities become more lucrative. The literature (Jean-Louis Combes et al, 2015, IMF ARA 2011) also suggests that the exchange rate regime maintained by emerging market countries constraint them to different kinds of crises. Consequently, we 
add an exchange rate regime dummy (fixed exchange rate regimes $=0$; and floating exchange rate regimes $=1$ ) to account for the difference. These variables have been captured in models 1 and 2 estimated below. The third model has been motivated by the fact that OLS results of the four adequacy measures as independent variables against reserves show only the risk weighted metrics measure as significant at the 1 percent level. We therefore develop a hybrid of model 1 which includes the risk weighted metrics measure as an independent variable. The risk weighted measure has been added as a dummy variable which takes the value of 1 , if the country's risk weighted value is within the adequacy level of 100-150 percent or 0 percent otherwise. The purpose of this hybrid model is to measure if the demand for reserves is shifting towards being determined by the need for broad based adequacy than the traditional current account buffer. The demand models (log-linearized to facilitate interpretation) have been specified as follows:

$\log (\text { Reserve/GDP })_{\mathrm{it}}=\mathrm{B}_{0}+\mathrm{B}_{1} \log ($ import/GDP $)$ it $+\mathrm{B}_{2} \log (\text { Export+Import/GDP })_{\mathrm{it}}+\mathrm{B}^{3}$

$\log (\text { short term debt/GDP })_{\mathrm{it}}+\mathrm{B}_{4} \log (\mathrm{M} 2 / \mathrm{GDP})^{\mathrm{it}}+\mathrm{B}_{5}$ Opcost $_{\mathrm{it}}+\mathrm{B}_{6}(\text { Ex. Regime Dummy })_{\mathrm{i}}+\mathrm{E}_{\mathrm{it}}$

Log $(\text { Reserve/GDP })_{\text {it }}=\mathrm{B}_{0}+\mathrm{B}_{1} \log (\text { import } / \mathrm{GDP})_{\mathrm{it}}+\mathrm{B}_{2} \log (\text { Export/GDP })_{\mathrm{it}}+\mathrm{B}_{3} \log$

$(\text { short term debt/GDP })_{\mathrm{it}}+\mathrm{B}_{4} \log (\mathrm{M} 2 / \mathrm{GDP})_{\mathrm{it}}+\mathrm{B}_{5}$ Opcost $_{\mathrm{it}}+\mathrm{B}_{6}(\text { Ex. Regime Dummy })_{\mathrm{i}}+\mathrm{E}_{\mathrm{it}}$

$\log (\text { Reserve/GDP })_{\text {it }}=\mathrm{B}_{0}+\mathrm{B}_{1} \log (\text { import/GDP })_{\mathrm{it}}+\mathrm{B}_{2} \log (\text { Export+Import/GDP })_{\mathrm{it}}+$

$\mathrm{B}_{3} \log (\text { short term debt/GDP })_{\text {it }}+\mathrm{B}_{4} \log (\mathrm{M} 2 / \mathrm{GDP})_{\mathrm{it}}+\mathrm{B}_{5}$ Opcost $_{\mathrm{it}}+$

$\mathrm{B}_{6}(\text { Ex. Regime Dummy })_{i}+\mathrm{B}_{7}$ (Risk weighted dummy $)_{\mathrm{i}}+\mathrm{E}_{\mathrm{it}}$

\section{RESULTS}

The results on Table 4 show that the trade openness variables (export+import / GDP and export/GDP) in both the standard and hybrid models are positive and significant as expected, signifying that the middleincome emerging market countries demand a higher precautionary level of reserves to cushion the terms of trade shocks as trade with other countries increase. For the current account variable (import/GDP), the hybrid model performs the best (negative and significant), showing that increased imports deplete reserves. Similarly, the financial stability variable (broad money/GDP) is positive and significant (in the standard models), since it is expected that increases in the money supply, increases economic activity and the demand for reserves. This result is in-line with Obstfeld et al. (2002) who argued that financial stability is highly correlated with reserve holdings, especially for financially liberalized countries. Interestingly, the coefficient for short term debt is negative and significant in the standard models, suggesting that increases in the liabilities in these countries decrease the demand for reserves. This is a deviation from other studies that have found this variable not to be a good predictor of reserve demand (Ghosh et al. 2017). The negative and significant result derived in this sample of countries could also signify the fact that financial liberalization affords these middle-income emerging market countries the ability to borrow from other sources, thereby reducing the demand for reserves. The short-term debt variable in the hybrid model on the other hand is insignificant, reflecting what other studies have found. As expected, we find from the standard models that as the opportunity cost of holding reserves increase, the demand for reserves decreases. We find that the fixed exchange rate dummy is positive and significant, confirming the notion that countries with pegged currencies usually need to hold more reserves to maintain the peg. In the hybrid model, we find that the risk weighted measure is positive and significant (1 percent level), suggesting that as the risk of potential drains in the middle-income emerging market countries increase, these countries hold more reserves. In this third model, we find that the risk weighted metrics variable has the highest estimated coefficient, followed by the current account variable and thereafter by the trade openness variable. We see the same trend with model 1, as the financial variables (exchange rate regime, opportunity cost of holding reserves) have higher coefficient values than the current account variables. 
TABLE 4

GMM RESULTS OF RESERVE DEMAND DETERMINANTS

\begin{tabular}{|l|l|l|l|}
\hline & Equation 1 & Equation 2 & Equation 3 \\
\hline Variables & Coefficient & Coefficient & Coefficient \\
\hline Log Export+Import / GDP & $0.0147^{*}$ & & $0.0514^{* * *}$ \\
& $(0.0083)$ & & $(0.0185)$ \\
\hline Log Import/GDP & 0.0105 & $0.0202^{*}$ & $-0.0725^{* *}$ \\
& $(0.0180)$ & $(0.0111)$ & $(0.0331)$ \\
\hline Log Export/GDP & & 0.0103 & \\
& & $(0.0136)$ & \\
\hline Log Short term debt / GDP & $-0.0712^{* * *}$ & $-0.0601 * * *$ & 0.0088 \\
& $(0.0117)$ & $(0.0193)$ & $(0.0307)$ \\
\hline Log Broad money / GDP & $0.0098^{* * *}$ & $0.0082^{* * *}$ & 0.0009 \\
& $(0.0017)$ & $(0.0018)$ & $(0.0056)$ \\
\hline Opportunity Cost & $-0.3180^{* * *}$ & $-0.2800^{* *}$ & 0.2586 \\
& $(0.1238)$ & $(0.1401)$ & $(0.2586)$ \\
\hline Dummy-Fixed Exchange rate regime & $0.4641^{* * *}$ & $0.3445^{* *}$ & 0.3055 \\
& 0.1656 & $(0.1777)$ & $(0.4100)$ \\
\hline Risk Weighted Dummy & & & $1.0731^{* * *}$ \\
& & & $(0.3401)$ \\
\hline
\end{tabular}

Note: Coefficients are reported with standard errors in brackets; The variables are significant at the 10*, $5^{* *}$ and $1 * * *$, respectively.

In forecasting reserves for 2020, we chose the estimated demand model with the most significant variables and employ it to forecast what the level of reserves should have been in 2020. The sample of countries chosen from the group of seventy middle income emerging market countries in the study is reported on Figure 1. The results show that most of the countries had reserves in 2020 that were below the forecast, implying that these countries were vulnerable during the Covid-19 years. We further analyze the 2020 actual (A) reserves divided by 2020 forecasted (F) reserves such that when the A/F $>1$, this implies that the countries outperformed their forecast. Alternatively, when $\mathrm{A} / \mathrm{F}<1$, this implies an underperformance. The results (Figure 1) show that the best performing countries are Brazil, Algeria, Vietnam, Philippines, and Morocco with scores between 1.27 to 3.12; and the worst being Turkey (0.35), Kazakhstan (0.23) and Tunisia (0.11). 
FIGURE 1

SELECT MIDDLE INCOME EMCS 2020 RESERVE ACTUALS TO FORECAST

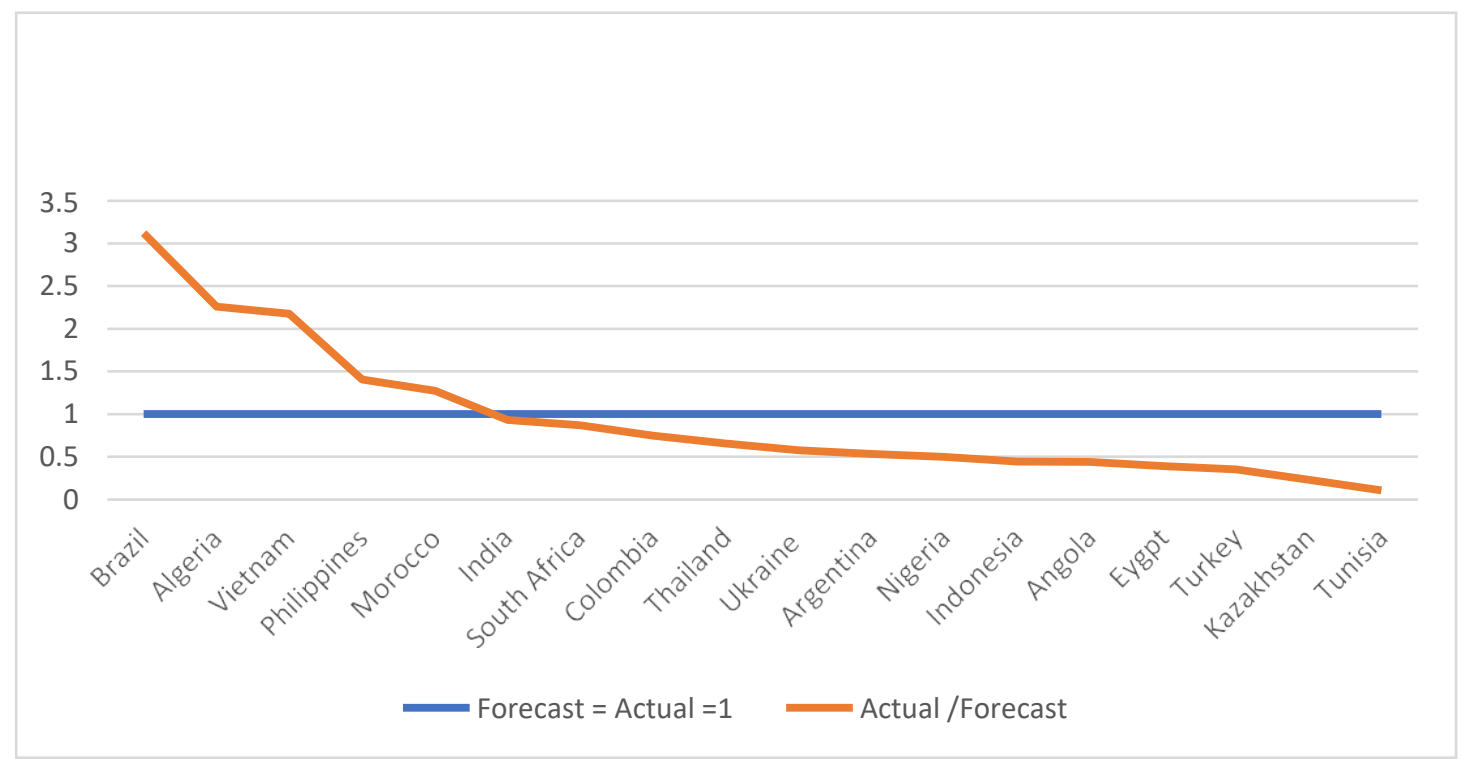

*Drawn from authors OLS estimations using equation 1 (without regime dummy)

We assess the reserve adequacy levels of the emerging market countries based on four established benchmarks: import cover, M2 to reserves, reserve to STD, and the IMF's risk weighted metrics measure. The results are reported on Table 5. Based on the import cover for 2019, 83 percent of the countries meet the required three months of import coverage and 34 at six months of coverage. Given that the Covid-19 economic disruptions lingered beyond 2020, this left 66 percent of the EMCs in vulnerable current account positions. The M2 to reserves ratio measures the risk of capital flight and suggests that reserves be at least 20 percent of M2 (i.e., an M2 to reserve ratio of 5). Table 5 shows that 77 of the EMCs fall short of reserve adequacy based on this measure in 2019. Similarly, the reserve to STD ratio classifies the nations as mostly inadequate, as only 4 percent of the countries have reserves that cover 100 percent of short-term debt. Using the risk weighted metrics, we find that about 61percent of the countries in 2010 had adequate reserves, but nine years later in 2019, only 44 percent of the countries had reserves that were in the 100 to 150 percent sufficiency range. Furthermore, a simple average of the measures based on exchange rate regimes exhibit that the floating exchange rate EMCs performed better under all the measures than fixed exchange rate regime countries (Figure 2).

TABLE 5

MIDDLE INCOME COUNTRIES MEASURES OF RESERVE ADEQUACY (2010 AND 2019)

\begin{tabular}{|l|l|l|l|l|l|l|l|l|}
\hline \multirow{2}{*}{ Countries } & \multicolumn{2}{l|}{$\begin{array}{l}\text { Import Cover } \\
\text { Reserve/Import* }\end{array}$} & \multicolumn{2}{l|}{ Reserve/M2* } & \multicolumn{2}{l|}{ Reserve/STD* } & \multicolumn{2}{l|}{$\begin{array}{l}\text { Risk Weighted } \\
\text { Metrics** }\end{array}$} \\
\hline & 2010 & 2019 & 2010 & 2019 & 2010 & 2019 & 2010 & 2019 \\
\hline Albania & 4.86 & 5.94 & 3.71 & 3.19 & 29.25 & 48.13 & 168.23 & 154.81 \\
\hline Algeria & 36.78 & 14.47 & 0.65 & 1.93 & 1.04 & 3.15 & n/a & n/a \\
\hline Angola & 5.41 & 6.43 & 1.48 & 1.71 & 23.21 & 17.28 & 148.13 & 93.32 \\
\hline Argentina & 7.28 & 5.95 & 2.05 & n/a & 31.44 & 149.87 & n/a & 61.01 \\
\hline Armenia & 4.37 & 4.18 & 1.31 & 2.25 & 35.14 & 55.96 & 168.99 & 123.61 \\
\hline Azerbaijan & 5.35 & 3.96 & 2.05 & 2.41 & 15.59 & 8.76 & n/a & n/a \\
\hline
\end{tabular}




\begin{tabular}{|c|c|c|c|c|c|c|c|c|}
\hline Bangladesh & 4.32 & 5.86 & 6.06 & 5.89 & 26.37 & 29.78 & $\mathrm{n} / \mathrm{a}$ & $\mathrm{n} / \mathrm{a}$ \\
\hline Belarus & 1.57 & 2.48 & 3.36 & 2.47 & 236.07 & 108.52 & 29.85 & 45.12 \\
\hline Belize & 2.69 & 2.38 & 4.80 & 5.69 & 3.17 & 1.52 & $\mathrm{n} / \mathrm{a}$ & $\mathrm{n} / \mathrm{a}$ \\
\hline Bhutan & 11.75 & 9.99 & 1.13 & 1.55 & 0.60 & 2.24 & $\mathrm{n} / \mathrm{a}$ & $\mathrm{n} / \mathrm{a}$ \\
\hline Bolivia & 16.39 & 5.99 & 1.41 & 5.51 & 3.46 & 10.58 & 282.57 & 62.94 \\
\hline Bosnia $\mathrm{H}$ & 5.81 & 7.32 & 2.09 & 2.09 & 26.05 & 4.98 & $\mathrm{n} / \mathrm{a}$ & $\mathrm{n} / \mathrm{a}$ \\
\hline Botswana & 12.40 & 8.14 & 0.80 & 1.28 & 4.57 & 2.26 & $\mathrm{n} / \mathrm{a}$ & $\mathrm{n} / \mathrm{a}$ \\
\hline Brazil & 10.44 & 12.70 & 5.68 & 5.04 & 22.70 & 22.40 & 128.91 & 146.79 \\
\hline Bulgaria & 7.10 & 7.24 & 1.99 & 2.10 & 87.92 & 35.46 & 104.14 & 149.51 \\
\hline Cabo Verde & 3.80 & 6.46 & 3.49 & 2.74 & 0.00 & 0.01 & $\mathrm{n} / \mathrm{a}$ & $\mathrm{n} / \mathrm{a}$ \\
\hline Cambodia & 5.60 & 8.10 & 1.23 & 1.55 & 9.93 & 18.18 & $\mathrm{n} / \mathrm{a}$ & $\mathrm{n} / \mathrm{a}$ \\
\hline China & 22.57 & 13.75 & 3.68 & 8.77 & 17.58 & 37.40 & 187.69 & 80.47 \\
\hline Colombia & 5.44 & 7.61 & 3.87 & 2.99 & 28.18 & 30.25 & 135.91 & 135.51 \\
\hline Comoros & 6.36 & 6.84 & 1.27 & 1.65 & 3.03 & 0.78 & $\mathrm{n} / \mathrm{a}$ & $\mathrm{n} / \mathrm{a}$ \\
\hline Costa Rica & 3.86 & 4.55 & 4.16 & 3.24 & 52.54 & 30.83 & 82.26 & 7.26 \\
\hline Djibouti & 5.88 & 1.22 & 4.24 & 4.27 & 48.80 & 74.80 & $\mathrm{n} / \mathrm{a}$ & $\mathrm{n} / \mathrm{a}$ \\
\hline Dominican & 2.30 & 3.64 & 4.51 & 3.44 & 45.28 & 28.35 & $\mathrm{n} / \mathrm{a}$ & $\mathrm{n} / \mathrm{a}$ \\
\hline Ecuador & 1.33 & 1.21 & 9.22 & 15.02 & 40.57 & 29.04 & $\mathrm{n} / \mathrm{a}$ & $\mathrm{n} / \mathrm{a}$ \\
\hline Egypt & 6.70 & 3.76 & 4.78 & 5.25 & 8.50 & 25.32 & 107.35 & 69.57 \\
\hline El Salvador & 5.84 & 3.80 & 3.74 & 3.57 & 29.00 & 49.79 & 63.64 & 69.78 \\
\hline Eswatini & 2.96 & 2.11 & 1.50 & 2.89 & 27.60 & 7.14 & $\mathrm{n} / \mathrm{a}$ & $\mathrm{n} / \mathrm{a}$ \\
\hline Fiji & 3.96 & 3.36 & 2.95 & 3.83 & 10.84 & 5.08 & $\mathrm{n} / \mathrm{a}$ & $\mathrm{n} / \mathrm{a}$ \\
\hline Georgia & 3.94 & 3.17 & 1.54 & 2.49 & 48.62 & 64.91 & 124.07 & 92.59 \\
\hline Ghana & 4.25 & 2.90 & 1.85 & 2.38 & 40.55 & 61.33 & $\mathrm{n} / \mathrm{a}$ & $\mathrm{n} / \mathrm{a}$ \\
\hline Guatemala & 4.53 & 7.41 & 3.23 & 2.80 & 26.65 & 4.78 & 154.15 & 211.32 \\
\hline Guyana & 5.17 & 1.66 & 1.92 & 4.70 & 42.62 & 20.85 & $\mathrm{n} / \mathrm{a}$ & $\mathrm{n} / \mathrm{a}$ \\
\hline Honduras & 3.74 & 5.07 & 3.01 & 2.71 & 13.85 & 13.52 & 120.27 & 129.17 \\
\hline India & 7.76 & 8.27 & 4.33 & 4.71 & 18.79 & 23.04 & 157.62 & 152.87 \\
\hline Indonesia & 6.87 & 6.32 & 2.83 & 3.36 & 34.35 & 34.68 & 91.17 & 76.22 \\
\hline Jamaica & 4.17 & 4.82 & 2.31 & 2.27 & 43.55 & 62.48 & $\mathrm{n} / \mathrm{a}$ & $\mathrm{n} / \mathrm{a}$ \\
\hline Kazakhstan & 5.11 & 4.53 & 2.04 & 1.92 & 31.36 & 31.04 & 75.12 & 71.85 \\
\hline Kenya & 5.11 & 4.53 & 3.73 & 3.79 & 24.10 & 28.64 & 90.97 & 39.08 \\
\hline Kosovo & 2.89 & 2.53 & 2.85 & 3.96 & 55.94 & 87.59 & $\mathrm{n} / \mathrm{a}$ & $\mathrm{n} / \mathrm{a}$ \\
\hline Kyrgyz & 4.99 & 4.50 & 0.88 & 1.36 & 11.33 & 21.36 & $\mathrm{n} / \mathrm{a}$ & $\mathrm{n} / \mathrm{a}$ \\
\hline Maldives & 2.18 & 1.96 & 3.41 & 3.09 & 40.05 & 44.11 & 64.91 & $\mathrm{n} / \mathrm{a}$ \\
\hline Mexico & 4.13 & 4.01 & 2.69 & 2.62 & 35.71 & 34.25 & $\mathrm{n} / \mathrm{a}$ & $\mathrm{n} / \mathrm{a}$ \\
\hline Moldavia & 4.61 & 5.23 & 1.75 & 1.67 & 85.63 & 65.53 & 166.33 & 183.59 \\
\hline Mongolia & 6.11 & 4.67 & 1.51 & 1.79 & 15.98 & 67.83 & 220.65 & 83.77 \\
\hline
\end{tabular}

Note: Table 5 includes a list of 70 middle income EMCs for which data are consistently available for the study period 2010-2019. *Data from World Bank’s World Development Indicators; **Author's Calculations. 
FIGURE 2

RESERVE ADEQUACY MEASURES FOR SELECTED MIDDLE INCOME EMCS: FIXED VS. FLOATING EXCHANGE RATE REGIMES - 2019

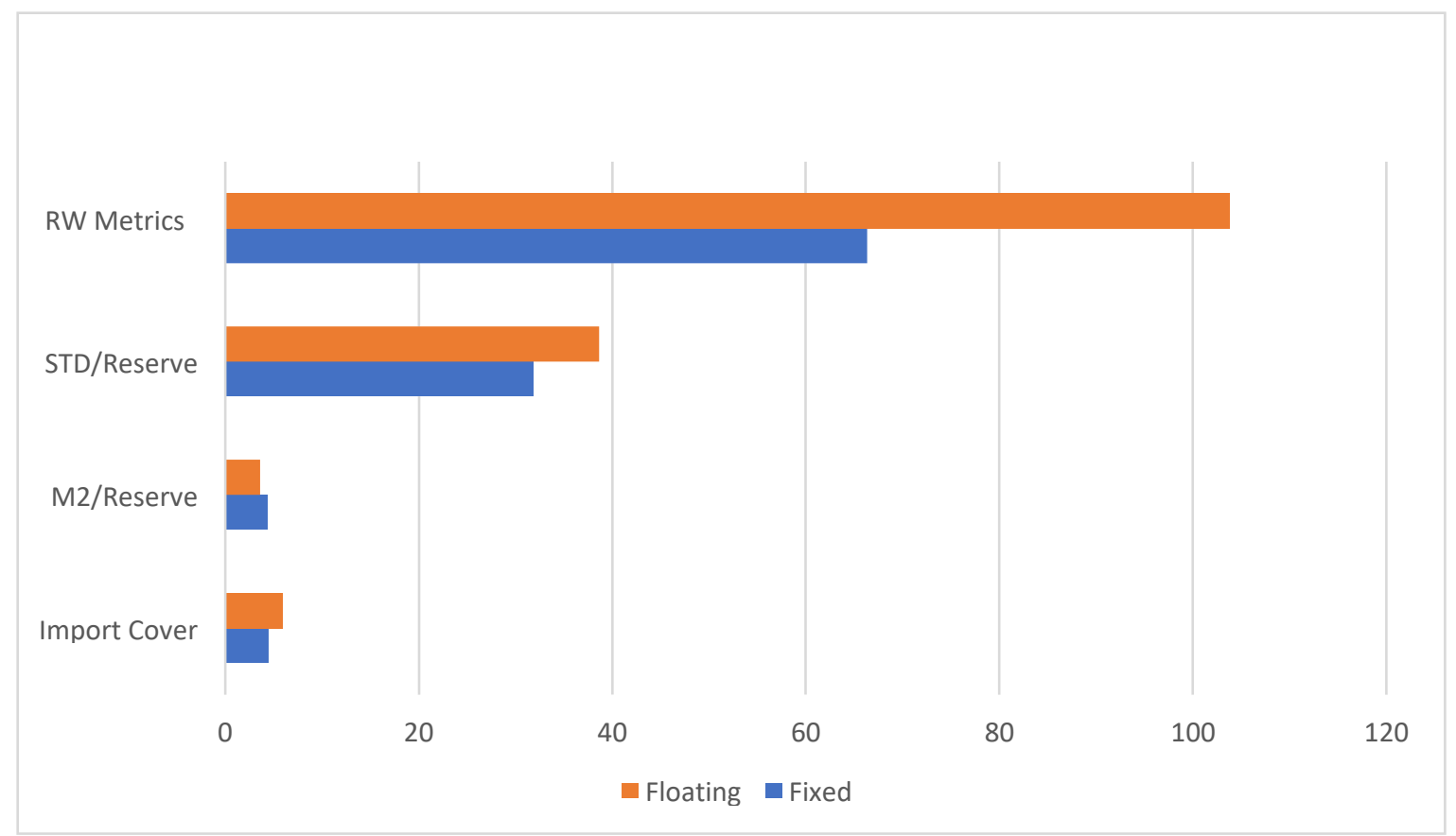

Finally, we have selected countries that have 2019 data for all four measures and ranked them from the largest coverage value to the least for each measure (Figure 3 ). We thereafter combined the four rankings to get a composite rank, with the least values being the best performers in terms of reserve adequacy. The best performing countries based on all four measures are Thailand, Bulgaria, China, Brazil, and India. Of the top five, Thailand and Brazil meet the adequacy levels based on all the measures except the reserves to STD ratio. Additionally, Bulgaria and India meet the import cover and risk weighted metric levels, while China has sufficient reserves based on the import cover and M2 to reserve ratio. The lowest ranked countries are Kazakhstan, Costa Rica, Belarus, Kenya, and Ukraine. While all these countries satisfied only the import cover level, only Belarus satisfied the reserve to STD threshold. 
FIGURE 3

SELECTED MIDDLE INCOME EMERGING MARKET COUNTRIES, SHOWING RANK AND SCORE SUM OF ALL MEASURES - 2019

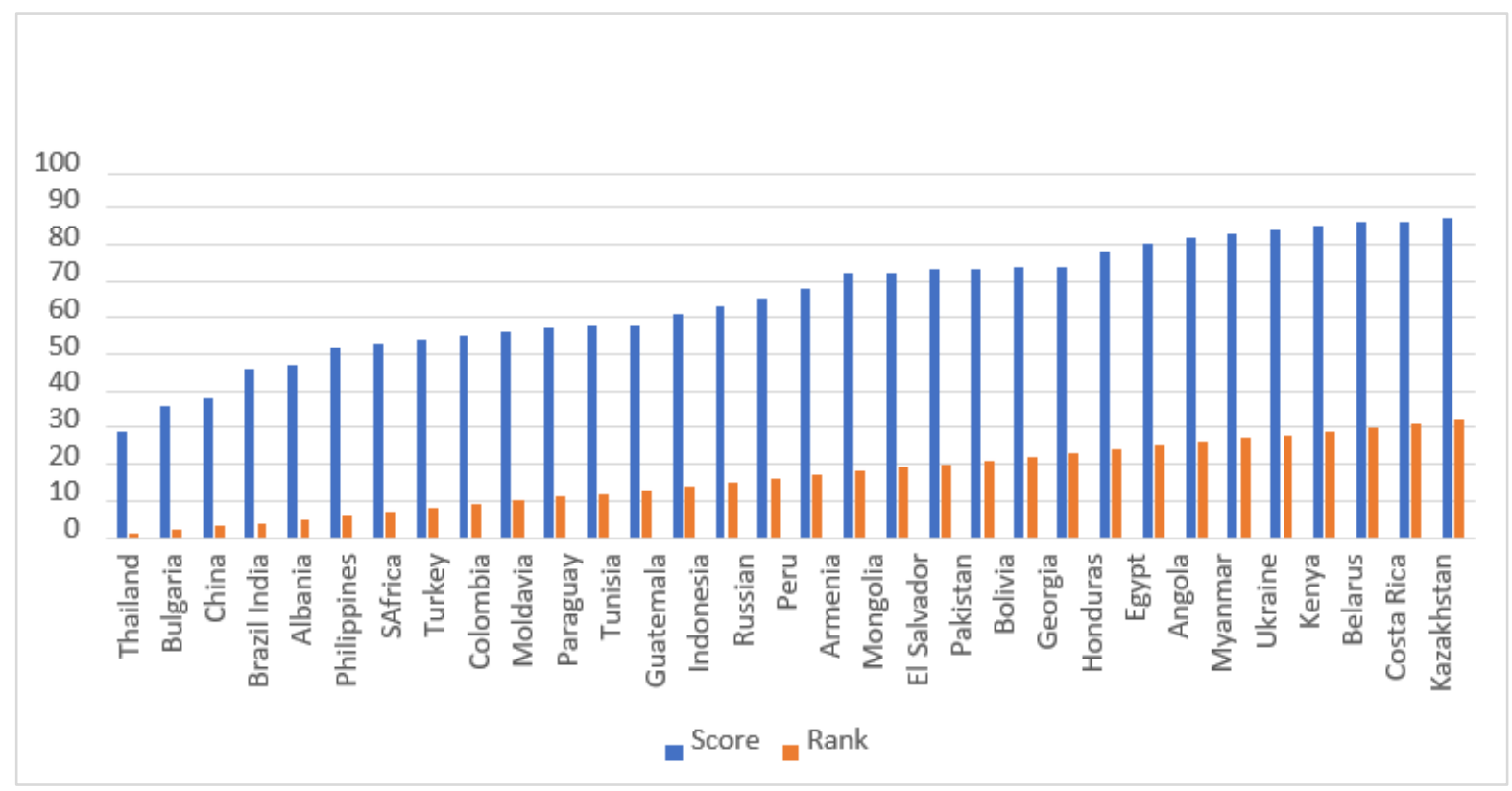

\section{CONCLUSION}

This paper finds that regardless of the method used either traditional or the risk-weighted measure to scrutinize FCR adequacy, it was observed that most of the middle-income EMCs were on the border line in terms of reserve adequacy in 2019. This result placed them in a vulnerable position that could become more constraining, should Covid-19 linger beyond 2021. This finding is supported by the fact that the actual 2020 reserves for most of the countries fell below the forecasted levels. It is also apparent that the adequacy levels for most of the countries dwindled between 2010 and 2019, placing these countries by 2020 in vulnerable reserve positions, given the persistency of Covid-19.

The traditional measures of reserve adequacy, namely, import cover-66 percent; M2/Reserves-77 percent; and Reserves/STD-96 percent, predict higher vulnerabilities faced by these countries from a potential Covid-19 capital inflow crisis than the risk weighted metric method - 56 percent. The different outcomes could be explained by the fact that the ARA metric is based on four weighted components, that reflect a broad set of risks, while the traditional measures target specific risks. Furthermore, a comparison of reserve adequacy, based on all four measures by type of exchange rate regime, shows the floating rate countries doing relatively better than the fixed exchange rate countries. The best performing countries based on a composite ranking of all four measures are Thailand, Bulgaria, China, Brazil, and India, while the countries at the lower end are Kazakhstan, Costa Rica, Belarus, Kenya, and Ukraine. Meanwhile, most of the countries in 2020 ran the risk of a current account crisis, given their sizable external debt obligations and dependence on export income. The implication is that these countries would have to look to external sources, such as international capital markets and institutions, for their current account liquidity needs.

Finally, we observed in all three models that the trade related variables, which represent reserve demand for precautionary purposes, have smaller weights than the non-precautionary variables. The financial stability variables (fixed exchange rate dummy, broad money/reserves, and short- term debt/ reserves) carry a greater proportion of the weights than the trade related variables (export+import/GDP, export/GDP, and import/GDP). This lends support to the suggestion that the motivations for holding reserves by EMCs may be shifting away from trade related vulnerabilities and moving towards mitigating contemporary 
susceptibilities in the financial sector(such as capital flight, exchange rate, or debt repayment issues). We also observe that reserve demand is influenced by the need to meet a more broad-based adequacy level with less emphasis being placed on individual sectorial vulnerabilities, as defined by the precautionary motive.

\section{REFERENCES}

Aizenman, J., \& Lee, J. (2007). International Reserves: Precautionary versus Mercantilist Views, Theory and Evidence. Open Economies Review, 18(2), 191-214.

Aizenman, J., \& Lee, J. (2008). Financial versus Monetary Mercantilism: Long run View of Large International Reserve Hoarding. The World Economy, 31.

Aizenman, J., \& Marion, N.P. (2003). The High Demand for International Reserves in the Far East: What is Going On? Journal of the Japanese and International Economies, 17, 370-400.

Arellano, M., \& Bond, S. (1991). Some Tests for Panel Data: Monte Carlo Evidence and an Application to Employment Equations. Review of Economic Studies, 58(2), 277-297.

Arslan, Y., \& Cantú, C. (2018). Size of foreign exchange reserves. BIS working paper \# 104.

Bar-llan, A., \& Marion, N.P. (2009). A Macroeconomic Perspective on Reserve Accumulation. Review of International Economics, 17, 802-823.

Bastourre, D., Carrera, J., \& Ibariucia, J. (2009). Interaction between Capital Flows and Commodity Prices. Review of International Economics, 17, 861.

Beck, T., Flynn, B., \& Homanen, M. (2020). Covid-19 in Emerging Markets: Firm Survey Evidence. Vetted and Real Time Papers, 38. Retrieved from https://voxeu.org/article/Covid-19- emergingmarkets-firm-survey-evidence

Borio, C., \& Disyatat, P. (2015). Capital flows and the current account: Taking financing (more) seriously. Bank of International Settlements (BIS) Working Papers \#525.

Combes, J., Minea, A., \& Sow, M.N. (2015). Crises and Exchange Rate Regimes: Time to break down the bipolar view? Retrieved from https://halshs.archives-ouvertes.fr/halshs-00944372v2

Csavas, C., \& Csom-Biro, G. (2017). Indicators Used for the Assessment of the Emerging and Developing Countries. International Trends in the Mirror of Theories. Financial and Economic Review, 16.

Davis Scott, J., Crowley, D., \& Morris, M. (2018). Reserve Adequacy Explains Emerging Market Sensitivity to U.S. Monetary Policy. Federal Reserve Bank of Dallas Economic Letters, 13(9).

Fisher, S. (2001). Opening Remarks. IMF/World Bank International Reserves: Policy Issues Forum, Washington DC.

Ghosh, A.R., Ostry, J.D., \& Tsangarides, C.G. (2014). Accounting for Emerging Market Countries' International Reserves: Are Pacific Rim Countries Different? Journal of International Money and Finance, 49, 52-82.

Ghosh, A.R., Ostry, J.D., \& Tsangarides, C.G. (2017). Shifting Motives: Explaining the Buildup in Official Reserves in Emerging Markets Since the 1980s. IMF Economic Review, 65(2), 308-363.

Greenspan, A. (1999). Currency Reserves and Debt. Remarks before the World Bank Conference on Recent Trends in Reserves Management, Washington, D.C. Retrieved from http://www.federalreserve.gov/boardDocs/speeches/1999/19990429. htm

Gurnain, P.K. (2013). Estimating policy rules for capital controls. IMF 6/20. Matthew Malley. Retrieved from https://www.imf.org/external/pubs/ft/wp/2013/wp1370.pdf

Ho, C., \& McCauley, R.N. (2003). Living with Flexible Exchange Rates: Issues and Recent Experience in Inflation Targeting Emerging Market Economies. BIS Working Paper \#130.

Moghadam, R., Ostry, J., \& Sheehy, R. (2011). Assessing reserve adequacy. IMF Policy Paper. Retrieved from https://www.imf.org/external/np/pp/eng/2011/021411b.pdf

Obstfeld, M.J., Shambaugh, J.C., \& Taylor, A.M. (2010). Financial Stability, the Trilemma, and International Reserves. American Economic Journal, 2, 57-94.

Olivier, J. (2007). International Reserves in Emerging Market Countries: Too Much of a Good Thing? Brookings Papers on Economic Activity: 1, Brookings Institution. 
Park, D., \& Estrada, G.B. (2009). Are Developing Asia's Foreign Exchange Reserves Excessive? An Empirical Examination. African Development Bank Economics Working Paper \#170.

Porter, N., \& Moriyama, K. (2015). Assessing Reserve Adequacy: Specific Proposals. IMF Policy Paper. Retrieved from https://www.imf.org/external/np/pp/eng/2014/121914.pdf; https://www.imf.org/external/np/pp/eng/2013/111313d.pdf

Rojas-Suarez, L. (2020). Emerging markets are pressed for liquidity, but Central Banks don't issue the currency they need the most. Retrieved from https://internationalbanker.com/finance/emergingmarkets-are- pressed-for-liquidity-but-central-banks-dont-issue-the-currency-they-need-the-most/

Samaratunga, D., \& Perera, A. (2015). Demand for and Adequacy of International Reserves in Sri Lanka. Staff Studies, 42. http://doi.org/10.4038/ss.v42i1.4686

Summers, L.H. (2006, March 24). Reflections on Global Account Imbalances and Emerging Markets Reserves Accumulation. L. K. Jha Memorial Lecture, Reserve Bank of India, Mumbai. Retrieved from www.president.harvard.edu/ speeches/2006/0324_rbi.html

Wijnholds, J., \& Kapteyn, A. ( 2001). Reserve Adequacy in Emerging Market Economies. IMF Working Paper 01/143. 